\title{
TWO FOUNDATION INSCRIPTIONS FOR ABDULLĀH KHAN IN BUILDINGS OF BUKHARA
}

\author{
Ebaid, Sh. \\ Lecture in Islamic dept., Faculty of Archaeology, Cairo Univ, Egypt
}

E-mail: Sheblebaid@hotmail.com

\begin{abstract}
Bukhara is one of the most ancient cities of Central Asia. Most of the historic buildings in this romantic eastern city contain numerous varied inscriptions on many of the architectural elements. The contents of these inscriptions were both religious and secular. Among them were a number of Quranic verses and saying of the Prophet. Additionally, there were construction inscriptions which contained many titles, names of Khans and dates of completion. Bukharan foundation inscriptions are very short compared to those on Timurid architecture in Samarkand, which were of great historical and archaeological importance. Generally there are few foundation inscriptions known in Bukharan architecture. This fact highlights the importance of two unpublished foundation inscriptions for Abdullah Khan, one of them inside the northern iwan of Gaukushon madrassa, and the other a top the main entrance portal of the Abdullah Khan madrassa. These two inscriptions are also significant because they contain many titles that provide evidence for the political and religious circumstances of the rule of Abdullah Khan Additionally, the style of the script in the second inscription is unique in its shape, different from that of the rest of the inscriptions in the Central Asian region.
\end{abstract}

Keywords: Foundation inscriptions, Bukhara, Thuluth script, Gaukushon madrassa

\section{Introduction}

Bukhara (a) is one of the most ancient cities of central Asia. Most of the historic buildings in this romantic eastern city contain numerous varied inscriptions on many of the architectural elements, such as pishtaq or main portico, facades, drums of the domes, bodies of the minarets, interfaces of iwans overlooking the courtyards, mihrabs, interfaces between student rooms in madrassas, and other places. These inscriptions were typically carved on rectangular bands, both horizontal and vertical, and could be in many different sizes. The contents of these inscriptions were both religious and secular. Among them were a number of
Quranic verses and saying of the Prophet. Additionally, there were construction inscriptions which contained many titles, names of Khans and dates of completion. Bukharin foundation inscriptions are very short compared to those on Timurid architecture in Samarkand, which were of great historical and archaeological importance. The Timurid inscriptions name rulers, princes and princesses of the period. They also record many of the rulers' titles, construction dates, names of the buildings' owners, as well as the names of the construction directors and their jobs and titles. Generally there are few foundation inscriptions known in 
buildings of Bukhara. This fact highlights the importance of two unpublished foundation inscriptions for Abdullah Khan, one of them inside the northern iwan of Gaukushon madrassa ${ }^{(b)}$ and the other a top pishtaq of the Abdullah Khan madrassa ${ }^{(c)}$. These two inscriptions are also significant because they contain many titles that provide evidence for the political and religious circumstances of the rule of Abdullah Khan Additionally,

\subsection{Historical Background}

'Abdallāh khan b. Eskandar, a ruler of Transoxiana of the Shaybānīd dynasty, born in the year Dragon (thus Šarafnāma-ye Šāhī; =1532-33 A.D. 93839 H.) [1]. Abdallāh first provedhis power as a ruler in $958 \mathrm{H}$. / 1551; the country had been attacked by Nawrūz Ahmed khan of Tashkent and 'Abd allatīf khan of Samarqand. 'Abdallāh as summed his father's duties and successfully repulsed the attack. In the following years 'Abdallāh khan tried to extend his possessions westerly in the

\section{Inscriptions}

\subsection{The first inscription}

The first inscription is located inside the northern iwan of Gaukushon madrassa, pl. (1-a). The inscription appears on a rectangular band decorated with tiles and it was written with a Thuluth script in two levels. It was executed mostly in white on a dark-blue background, with some sections written
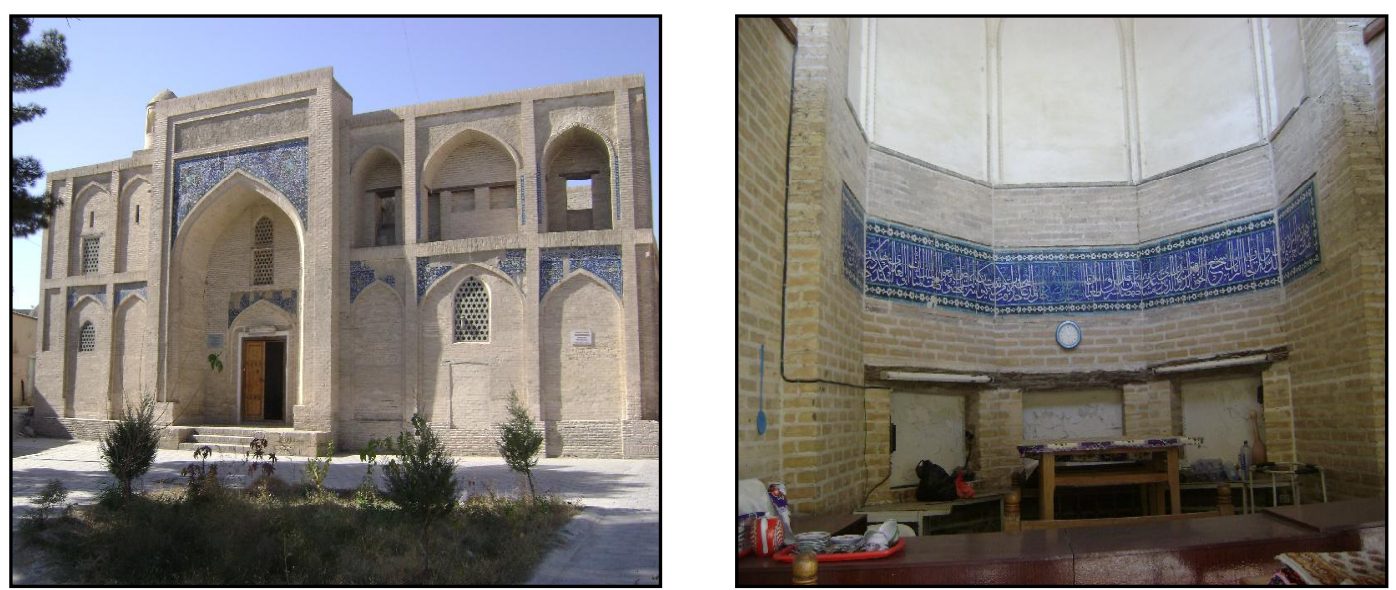

Plate (1) $\underline{\mathbf{a}}$ Gaukushon madrassa, $\underline{\mathbf{b}}$ The inscription located inside the northern iwan of Gaukushon madrassa the style of the script in the second inscription is unique in its shape, different from that of the rest of the inscriptions in the Central Asian region. In this analysis, I will attempt to highlight the styles of script demonstrated by of the inscriptions. This study will also present the contents of both inscriptions and tie them to the circumstances of their historical period, the rule of Abdullah ibn Iskander Khan.

direction of Bukhara and South - easterly in the direction of Karshi and Shar-I Sebz [2]. In 964 H. / 1556 'Abdallāh khan established his rule over Transoxania and made Bukhara his capital [3]. 'Abdallāh's last years were darkened by a quarrel with his only son 'Abd al-Mu'min, who ruled in Balkh, in the name of his father 'Abd al-Mu'min wanted to occupy the same position with regard to his father now growing old. 'Abdallāh was over taken by death in Samarqand 1006 H. / 1598 [1].

in light blue on the same dark background, pl. (1-b) it is a foundation inscription, executed in Kufic script with elaborate apices and elements of floraited Kufic and plated Kufic. It reads:" Allāh Akbar "God is Greatest" as shown in fig. (1) 


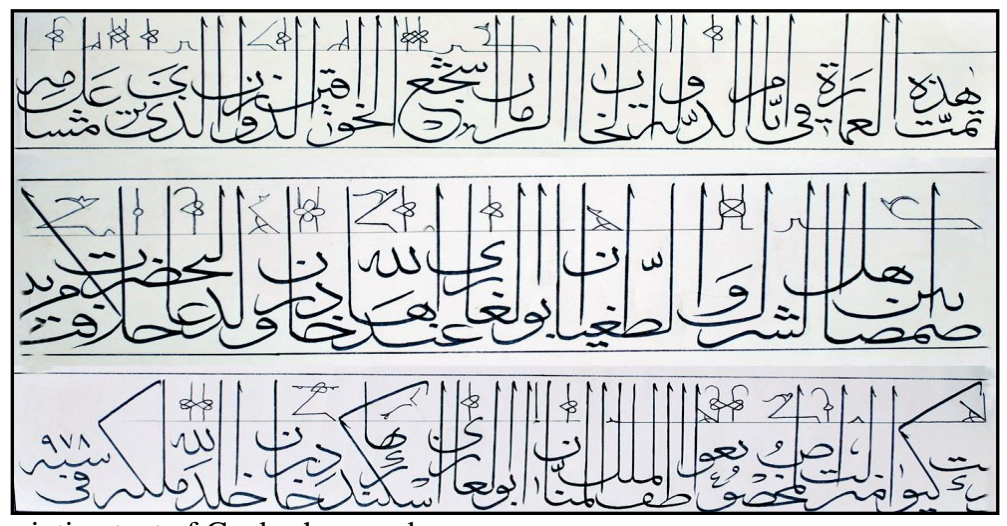

Figure (1) Inscription text of Gaukushon madrassa

\subsubsection{Description}

$$
\begin{aligned}
& \text { تمت هذه العمارة فى أيام لدولة الخـان الزمان أنشجع الخو اقين الدوران الذى ترى مشاعل صمصامه بين أهل }
\end{aligned}
$$

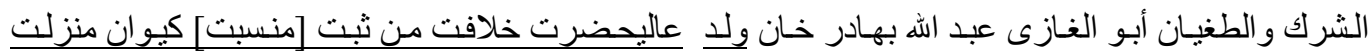

$$
\begin{aligned}
& \text { المخصوص بعو اطف الملك المنان أبو الغازى اسكندر بهادر خان خلد الله ملكه في سنة } 978
\end{aligned}
$$

\subsubsection{Transliteration}

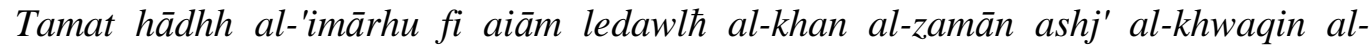
dawaran al-ladhi trī masha'il șmșāmhu bayn ahl al-shirk wa āl-țghian Abū'l-Ghāzī Abdu Bahādur Khan wald 'aalihadrati khlafti mansbt kivan manzlat al-makhșuws be'awatef al-malik al-manan Abū'l-Ghāzì Iskandar Bahādur Khank khallad allāh mulkhahu fi sanh 978

\subsubsection{Translation}

This building was completed during the era of the hegemony of the khan, most courageous of the khaqans, the flame of his sword is seen by infidels and tyrants, Abū'l-Ghāzī Abd Allah Bahādur 2.1.2. Comment

\subsubsection{Regarding form}

This inscription contains two languages, Arabic (Thuluth script) and Persian [4]. Arabic was used for most of it, with a few words written in Persian. However, some mistakes are present in the inscription, where both Arabic and Persian words are used together. This may have been caused by a local lack of 2.1.2.2. Regarding content

This inscription commemorates the completion of the construction of this madrassa, which was identified as a "building" without being more specific about its function. This formula is found a number of construction inscriptions in central Asia from Timurid period "This building was completed on the thirteenth of Safar, the year seven hundred and sixty two. $\left(14^{\text {th }}-15^{\text {th }}\right.$ centuries $)$, for
Khan, son of stateliness who attributed to Caliphate, rank of orbit, privileged with the love of the generous king, Abū'lGhāzī Iskandar Bahādur Khan, may God perpetuate his rule in the year 978

knowledge of Arabic culture. This occurs as one linguistic mistake in the first line of the inscription, where a Persian word is used al-dawaran, and in the third line of the inscription where an epithet of the Khan is given as: wald 'aalihadrati khlafti mansbt kivan manzlat

example on a mausoleum dated $762 \mathrm{H}$. / 1360 in the Shah Zende at Samarqand [5], or the mausoleum of Amir Zada dated to 778 H. / 1376 in the Shah Zende: "...counsel to raising this (b)uilding, its structure is higher .......6]. The same formula was used in the Shaibanid period as well. In a construction inscription of Nadir Devan Beghi Khānqāh 1092 H. / 1681. "In successes to construction of 
this spot, and completed it......" The inscription in the Gaukushon madrassa includes a number of titles, which help to elucidate the domestic and foreign policies of Abdullah Bahādur Khan. "Khan" was originally a central Asian title for a sovereign or military ruler, first used by medieval Altaic-speaking nomadic tribes living to throe north of China. It is also seen as a title in the Xianbei confederation [7], which was ruled by Genghis Khan. His title was khghan, 'Khan of Khans", and was used by several later Islamic Turkish dynasties from the Qarakhanids onwards [8]. This title was then used by all Uzbek rulers on the grounds that their leaders were descended from Genghis Khan [9]. In fact, Bukhara was called in this period, the "Khanate of Bukhara" [10]. The second title "khaqan" deals with the Great Sultans. The word reportedly is an Arab corruption of the Turkish title for sultans, "Qagan" [7]. This title was used by Abdullah Khan from the time he assumed power 959 H. / 1551. [11]. While the third title "the flame of his sword is seen by infidels and tyrants" is a phrase with political implications, using an Arabic name for sword, "semsām. One of the famous Arabic swords, belonging to Amre ibn mōd uakre-zobaide,

\subsection{The second inscription}

This inscription is located above the main eastern entrance portal of the Abdullah khan madrassa, pl. (2) the inscription is in a Rectangular band

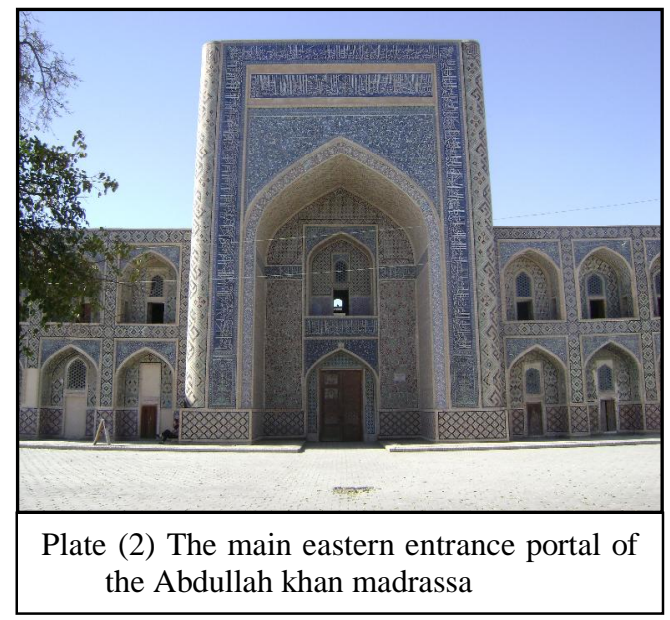

according to some accounts- [12]. The use of these titles shows that Abdullah Khan was clinging to Sunni Islam and confronting the pagan tribes that were living in the northern Steppe regions [13]. The epithet "Abū'l-Ghāzī" was used twice, once before the name of "Abdullah Bahadir" and again at the end of inscription before the name of His father, "Iskandar Khan". This is the epithet of militant Sunni, which referred to those who were engaged in wars in the way of Islam [7]. The same formula also appears on silver tangas minted in Tashkent: "Abdullah Bahadur Khan, khaqan, son of khaqan, son of khaqan, Abū'l-Ghāzī, May God perpetuates his rule and sovereignty, mint of Shermard Tashkent [14]. This epithet further appears on a number of coins of Shaibanid Khans, such as that of Abo Sāid Bahadur Khan: 'Khaqan Abū'lGhāzī Abo Sāid Bahadur Khan...... [14]. Finally, the title, -'aalihadrati khlafti"who attributed to the Caliphate". This may reveal the desire of Abdullah Khan to seek the help of the Ottoman Empire against Safavids, which they attacked repeatedly. The Ottoman sultans relied heavily on the Uzbeks to keep pressure on the Safavid rulers [15].

decorated with tiles and it was written in Thuluth scrip in several levels. The inscription was written in white on a blue background, as shown in fig. (2).

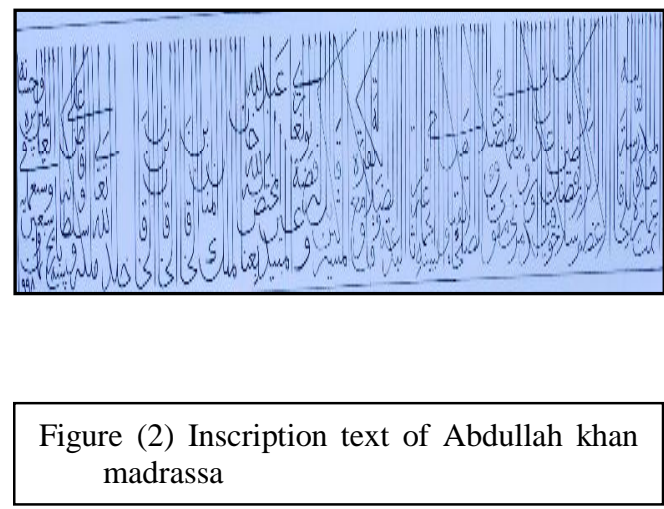


2.2.1. Description

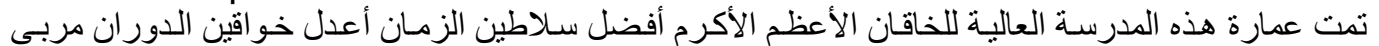

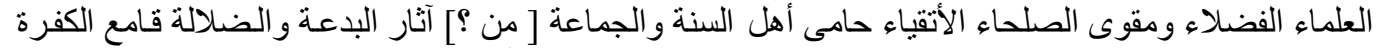

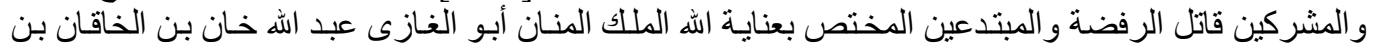

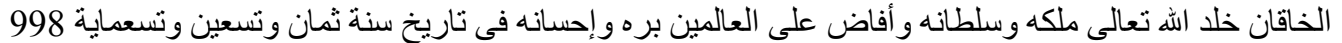
2.2.1.1. Transliteration

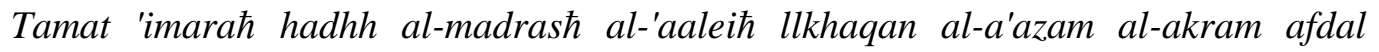
salatin al-zaman a'adal khawaqin al-dawaran murabi al-'ulama" al-fuzala" wa muqwi al-șulaha" al-atqia" al-fuzala" wa muqwi al-șulaha" al-atqia" hami ahl al-sunah wa

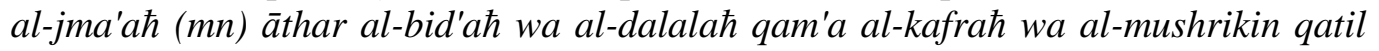

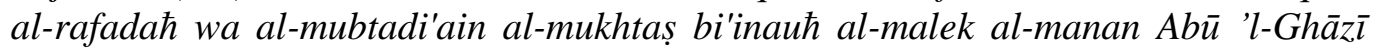
Abdullah khan ibn al-khaqan khallad Allāh mulkhahu wa sultānhu fi tarekh sanat thaman wa ts'in wa ts'umaih 998.

\subsubsection{Translation}

The building of this high madrassa was finished for the greatest, the most generous khaqan, the best sultan and the most just khaqan of all time, patron of virtuous scholars, and one who empowers the pious righteous, who shepherds the Sunnis and the nation away from novelty and the wrong path, suppressor of infidels and 2.2.2. Comment

\subsubsection{Regarding form}

The form of this inscription is different from that of other inscriptions in central Asia. The scribe extended the vertical letters, such as alif and laam, to touch the edges of the rectangular

the polytheists, slayer of deniers and heretics, he is endowed with the care of God, the generous king, Abū'l-Ghāzī Abdullah Khan, son of khaqan, son of khaqan, may God perpetuate his rule and sovereignty and let his dutifulness and kindness be bestowed on the people, in the year nine hundred and ninety-eight 998.

panel. This was influenced by the stone epigraphs of the fifteenth-century sultans of Bengal, in a mosque of Shah Zāda Dāniyāl, dated 905 H. / 1499 [16], as shown in fig. (3)

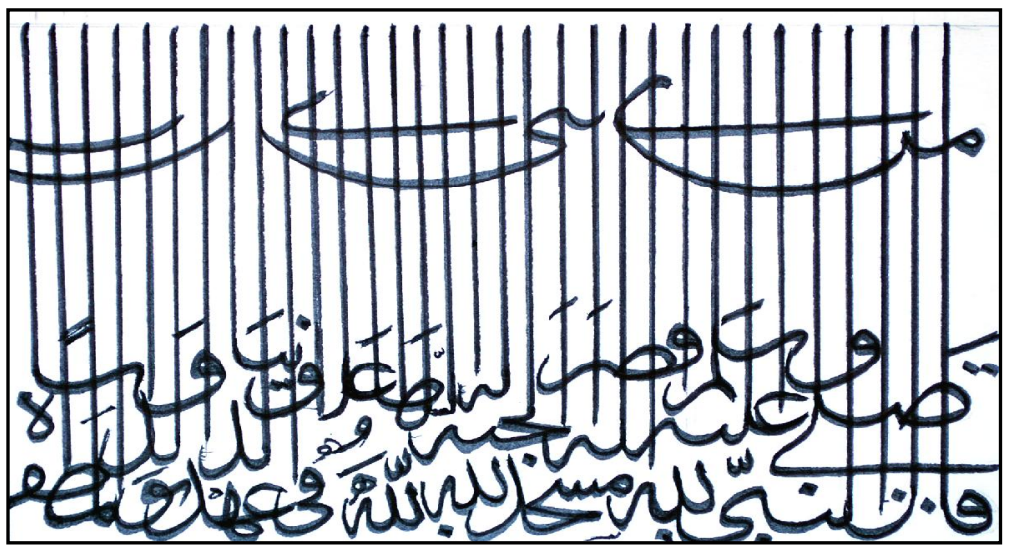

Figure (3) The stone epigraphy, in a mosque of Shah zāda Dāniyāl a mosque of Shah zāda Dāniyāl, Digby," The Fate of Daniyal, Prince of Bengal" Pl.1.

\subsubsection{Regarding content}

The opening of the text determines the function of the building as a "madrassa". It was described as "high" because it is distinguished by its exceptional stature and size. The

inscription includes several titles for Abdullah Khan, including the same titles that were mentioned in the previous inscription from the Gaukushon madrassa, as well as another title: afdal 
salatin al-zaman "the best sultan of all time". The year is given as $987 \mathrm{H}$. / 1579, in which Abdullah, having put an end to the dual system of government in Transoxania, received this homage from his subjects in Bukhara as an independent sovereign of all Turan [11]. The inscription also reveals two titles which present Abdullah Khan outside of his political life: murabi al-'ulama" alfuzala" wa muqwi al-șulaha" al-atqia" patron of virtuous scholars, and one who empowers the pious righteous. The title of -murabi al-'ulama" al-fuzala"- patron of virtuous scholars, we may note, originates under the Shaybanid khans, when theological studies were the only ones pursued at the time with any ardor. Among the most distinguished scholars was Mollah Zia-eddin, who died in 973 H. / 1565; and Khodja Djelal Juybāri, a pupil of Makhdum Aazam's, who was held in high regard as an ascetic, as a learned theologian and as an exegetical teacher. There was also Mollah Mushfiki, who wrote chronograms on the various buildings of Abdullah Khan as well as a few sonnets, poems and epigrams. He died in 994 H. / 1585 [10], finally; there was Khafiz Tanysh Bukhari, born in 949 - 960 H. / 1542- 1552, who was the author of Abdalla-nama. This book recounts in detail the events dating back to the reign of Abdullah Khan [17]. While the title-muqwi al-sulaha "alatqia" - "one who empowers the pious righteous" indicated the interest of Abdullah Khan in followers of Sufism, such as the Naqshbandi group in Tranoxania. He became an authority for the order's doctrine and practice which were laid down in his abundant writings. After the death of Makhdūm-I Ázam in 949 H. / 1542, the order was again divided. The Naqshbandis of Bukhara region supported Muhammad Islām Juybāri d.971 H. / 1563, whereas those of Tashkent and Ferghana recognized Lutfullāh chūsti d.980- 81 H. / 1572-73. The former had greater prestige and power and his descendants are known as the Shaybanids [18]. When Abdullah
Khan came to political prominence in Bukhara in $964 \mathrm{H}$. / 1556, his family's relations with the Juybaris already had a long history. Khwajah $\mathrm{Sa}^{\mathrm{C}} \mathrm{d}$ 's father, Khwajah Islam, had been a disciple of the most influential Naqshbandi figure, Mawarannahrin, during the first half of the sixtieth century. Abdullah Khan owed a good deal to Khwajah Islam [19]. Then, when the latter died in $971 \mathrm{H}$. / 1563, he transferred his sense of obligation and loyalty to Khwajah Islam's son and successor, Khwajah $\mathrm{Sa}^{\mathrm{C}} \mathrm{d}$. Next to the Khan himself, Khwajah $\mathrm{Sa}^{\mathrm{C}} \mathrm{d}$ was the most influential figure in Bukhara for a quarter of a century, until his death in 997 H. / 1588 [20]. The architectural monuments of the time of the Shaybanids owe their origin chiefly to the public spirit of Abdullah Khan as well as to the Suffi theological trends of the times. Numerous mosques, convents, madrassas, halls, and mausoleums were built during this historical milieu [10]. Additional titles reveal that the inscriptions reflected political events, highlighting one of the stages of a conflict between Sunnis and Shiites: hami

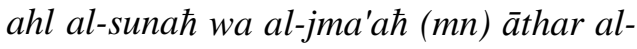

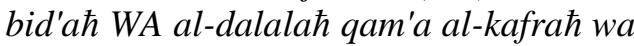
al-mushrikin qatil al-rafadah wa almubtadi'ain- (He) "Who shepherds the Sunnis and the nation away from novelty and the wrong path, suppressor of infidels and the polytheists, slayer of deniers and heretics" The specific conflict referred to is that between the Uzbeks and the Safavids, The beginning of this denominational difference, was when the Shi'ite Safavids conquered Iran in $907 \mathrm{H}$. / 1501, Khwajah Islam immigrated to the Uzbek court and devoted the rest of his life to the overthrow of the Safavids and Sunnism in Iran [21]. After Abdullah Khan effectively unified the state he immediately renewed his campaigns in Khorasan. In 997 H. / 1588, his army conquered heart, and the Qezelbāš and many civilians there were slaughtered. The next year Abd-al-mơmen, son of Abdullah Khan, who held Balk, took advantage, or the fact that Shah Ábbās 
had to face the Ottoman offensive in the west and conquered a great portion of Khorasan. Mašhad was captured after a four month siege and sacked it for three days. The Uzbeks slaughtered a great number of the city's inhabitants and plundered the shrine of Imam Álī al-Reżā [20]. According to some accounts Ábd-almormen's men even ordered the remains of Shah Tahmāsb, who had been buried near the shrine, to be exhumed and burnt and the ashes dispersed in the wind. During the subsequent years, all of Khorasan was captured by the Uzbeks, who also raided other regions as far as Yazd and Kāšān. Attempts at pushing them out of Khorasan remained unsuccessful until the death of Abdullah Khan in 1007 H. / 1598 [1].

\section{Conclusion}

The study confirmed that the use of thuluth script continued in the implementation of the documentary inscriptions on the buildings of Bukhara in the tenth century H./ sixteenth century D., and that is considered a continuation of the same style, which was followed in the Timured period (771-807H. / 1370-1405 ). - These two inscriptions are significant because they contain many titles that provide evidence for the political and religious circumstances of the rule of Abdullah Khan- The style of the script in the second inscription is different from that of other inscriptions in central Asia. The scribe extended the vertical letters, such as alif and laam, to touch the edges of the rectangular panel. This was influenced by the stone epigraphs of the fifteenth-century sultans of Bengal, in a mosque of Shah Zāda Dāniyāl, dated 905 H. / 1499

\section{Endnotes}

(a) Abu'l-Hasan Nishapuri in the book, "The Treasury of the Sciences", has contended this of the city of Bukhara, although the Oxus River is in the Middle of it. Ahmad ibn Muhammad ibn Nasr says that Bukhara went under many names. In his book he calls it "Numijkat", in another place; it is identified as "Bumiskat", while in yet another place it is written in Arabic madinat al-sufriya, "the copper city" and in another place, also in Arabic as madinat al-tujjar, "the city of merchants". For the names of the city, see: Abu'l- Hasan AlNarshakhi, "The History of Bukhara", Translated to English, R. N.,Frye, Mediaeval Academy of America (2007), pp.15-27.

(b) Gaukushon madrassa: is one of the largest ensembles of Bukhara and includes mosque, minaret and madrassa. In the past Gaukushon was the largest market square of Bukhara. It got its name due to the slaughterhouse, which once existed on this site, because "Gaukushon" is translated as "killing of bulls". - Pugatchenkova, G., (1983), "Crednua Asia cpravochuk-pyteodetele: Ezdatele- ctvo eckycctvo, Mockava Eckycctva Edetson Leoptsg Moscow, p.370; Arapov A.V., (2006), Masterpieces of Central Asia: Bukhara, Tashkent, p.69.

(c) Abdullah Khan madrassa: Abdullah Khan built the madrassa in 1589-90, as a residential theological school to the southwest of Bukhara's city center (Shahristan). Sheila A.S. Blair, Jonathan M. Bloom, The art and architecture of Islam 1250-1800, (Yale University Press, New Haven and London, 1995),p.201. He located the structure immediately opposite his earlier Madar-i Khan Madrassa. (1566-1567), thus creating another of Bukhara's typical double madrasa ensembles (kush madrassa). Abdullah Khan's madrasa was built during Bukhara's third and last great construction phase when numerous civic structures such as caravanserais, tims (markets), taks (domed market kiosks), hauz (lakes) and khanqahs (hospices). Richard D. McChesney., "Economic and Social Aspects of the public Architecture of Bukhara in the 1560s and 1570s", Islamic Art 2, (1987): p. 223. 


\section{References}

[1] Bregel, Yu., (1985). Abd Allāh Khan, in: Yarshater, E., (ed.) encyclopedia Iranica, Vol. I, Rutledge \& King Paul, London.

[2] Barthold, W., (1987). Abd Allāh Bin Iskandar, in: Brill's, E. (ed.) $1^{\text {st }}$ encyclopedia of Islam 1913-1936, Vol. I., Publishers M. Th. Houtsma aj Wensinck, Netherlands

[3] Bregel, Yu., (1982). Hāfiz Tanish, in: Bosworth, C. The Encyclopedia of Islam, new edition, Edited by C.E. Bosworth, E.J. Bril. Leiden

[4] Alparslan, A., (1978). Khatt, II - in Persia, in: Van Donzel, E., Lewis, B. \& Pellat, Ch. (eds.) The encyclopedia of Islam, Vol. IV, Leiden.

[5] Shishkin, V., (1970). Nadpisi v ansamble Shakhi-Zinde", Zodchestvo Uzbekistana, Vol. 2, pp: 7-71.

[6] Ebaid, Sh., (2002). Al-Nuqush alinshaiyya al-baqiya fi madinat Samarqand wa ahammyyatiha alatharyyiha", J. of Arts and Sciences, Menia Univ., Vol. 44, pp: 496-548.

[7] Al-Baāsha, H. (1978). Al-Alqab alislamiyya Fi 'l-ta'rikh wa 'l-Watha'iq Wa 'l-aāthaār, Daār al-Nahda, Cairo.

[8] Sir Gerard, C., (1972). An etymological dictionary of prethirteenth century Turkish, Oxford Univ. press, London.

[9] Takosh, M., (2009). Ta'rikh 'l-Dawlah Al-Safawi Fi Iran: 907-1148 /15011736, Dar Al-Nafaes, Bayrūt.

[10] Vambéry, V., (1873). History of Bukhara from the earliest period down to the present day, $2^{\text {nd }}$ ed. H.S. King \& Co., London.

[11] Ahmedov, B., (1996). O'zbekistonda Arablar Va Islom, Manuscript Center of Tashkent, Toshkent.

[12] Al-Askarī, A., (1933). Dewan alm'ane, Vol.1, Tahekiek Ahmed
Hassan Bsag, Dar Al-Kotob AlElmia, Cairo.

[13] Caākov, B. (1996). Istoriia Bukhara: 100 Vobrocove e otveto, Shark, Tashkent.

[14] Davidovich, E., (1992). Korpyc zolotech e cepebruanekh monet shaibanedov: XVIV, Eckycctvo, Mockva

[15] Karpat, K., (2002). Studies on Ottoman social and political history, Selected Articles and Essays, social, economic and political studies of the Middle East and Asia, Brill, Netherlands.

[16] Digby, S., (1973). The fate of Daniyal, prince of Bengal, in the light of an unpublished inscription", Bulletin of the School of Oriental and African Studies, University of London, Vol. 36 (3), pp: 588- 602.

[17] Azizkhodjayev, A., (1997). Bukhara: An oriental gem, Office of Publishing \& Printing Concern, Tashkent

[18] Adle, C., \& Habib, I., (2003). History of the civilizations of central Asia", Vol. V, Development in contrast from the sixteenth to the mid-nineteenth century, UNESCO publishing, Paris.

[19] Agahe, M., (Without date). Zobdat Al-Twarek, Institute of oriental studies, Uzbek academy of sciences, No. 822/3, Paper No. 21, Tashkent,

[20] McChesney, R., (1997). Shībānids, in: Bosworth, C., Van Donzel, E., \& Heinrichs, W. (eds.), The Encyclopedia of Islam, Vol. IX, Leiden.

[21] Black, A., (2001). The history of Islamic, political thought, from the prophet to the present, Edinburgh University Press and Rutledge, New York. 